\title{
PENGEMBANGAN LKS BERBASIS SAINTIFIK UNTUK MELATIH KETERAMPILAN BERPIKIR KRITIS SISWA SD
}

\author{
Indra Kusuma Wardani \\ Galuh Tisna Widiana \\ Universitas Pesantren Tinggi Darul 'Ulum \\ PP Darul ‘Ulum Tromol Pos 10 Peterongan Jombang \\ email : indrakusumawardani@mipa.unipdu.ac.id
}

\begin{abstract}
This research aims to develop scientific student worksheet based on indicators of critical thinking skills. This research uses Research and Development (R\&D) method with one group pre-test post-test design. The results showed $86.35 \%$ reliability, $92.64 \%$ validity, and $95.38 \%$ readability. $\mathrm{N}$-gain analysis reached high value criteria at indicator of questioning, responding, analyzing and conducting scientific experiments. Student activity dominant with worksheet duties $(73.93 \%$ and $71.37 \%)$ and conducting scientific experiment $(75.74 \%$ and $73.44 \%$ ). It can be concluded that the student worksheet meet the criteria of validity, practicality and effectiveness for practice the student scientific ability and critical thinking skills.
\end{abstract}

Keywords : student worksheet, scientific; critical thinking, primary school.

\begin{abstract}
Abstrak: Penelitian ini bertujuan mengembangkan LKS saintifik berdasarkan indikator keterampilan berpikir kritis. Penelitian ini menggunakan metode Research and Development $(R \& D)$ dengan desain penelitian one group pre-test post-test design. Hasil penelitian menunjukkan persentase reliabilitas $86,35 \%$; validitas $92,64 \%$; dan keterbacaan 95,38\%. Analisis n-gain berkriteria tinggi ditunjukkan pada indikator menanya, menanggapi pertanyaan, menganalisis dan melakukan percobaan ilmiah. Aktivitas siswa dominan pada kegiatan mengerjakan LKS (73,93\% dan 71,37\%) dan melakukan percobaan ilmiah $(75,74 \%$ dan $73,44 \%)$. Berdasarkan temuan penelitian dapat disimpulkan bahwa LKS memenuhi kriteria validitas, kepraktisan dan keefektifan sehingga layak untuk melatihkan kemampuan saintifik dan keterampilan berpikir kritis siswa.
\end{abstract}

Kata Kunci : LKS, saintifik, berpikir kritis, SD

Kegiatan pembelajaran pada muatan materi Ilmu Pengetahuan Alam (IPA) pada tingkat pendidikan dasar, SD/MI, bertujuan agar siswa memiliki kompetensi dalam mengembangkan pengetahuan dan pemahaman tentang teori dan konsep IPA. Kompetensi tersebut dapat dikuasai siswa jika siswa memiliki rasa ingin tahu terhadap fenomena atau peristiwa yang terjadi di alam dan lingkungannya. Rasa ingin tahu pada diri siswa akan memunculkan beragam pertanyaan dalam benaknya sehingga siswa akan termotivasi untuk mencari jawaban dari pertanyaan-pertanyaan tersebut. Peran guru dalam kegiatan pembelajaran di kelas sangat penting untuk membimbing siswa selama proses pencarian jawaban agar siswa dapat menggali lebih dalam tentang informasi yang disampaikan guru untuk mendapatkan pemahaman dan pengetahuan baru yang autentik bagi siswa (Sani, 2014:56). Guru dapat memberikan pengalaman langsung melalui serangkaian kegiatan intelektual yang bersifat konkret, rasional 
dan ilmiah. Oleh karena itu, kegiatan pembelajaran IPA tidak dapat dilepaskan dari peran guru untuk melatihkan kemampuan saintifik.

Kemampuan saintifik dapat dilatihkan ke siswa melalui kegiatan ilmiah yang meliputi kegiatan mengamati, menanya, menalar, mencoba dan membentuk jejaring yang mengkaitkan teori dan konsep pada mata pelajaran IPA dengan mata pelajaran lainnya (Kemendikbud, 2013). Kegiatan-kegiatan ilmiah tersebut menjadikan pembelajaran IPA tidak hanya menitikberatkan pada kemampuan kognitif siswa tetapi juga berfokus pada aktivitas siswa untuk mengkonstruksi pengetahuan berdasarkan informasi dan fakta yang ditemukannya. Pengkonstruksian informasi dan fakta ini dimaksudkan untuk memberikan pemahaman kepada siswa bahwa penguasaan teori dan konsep IPA tidak hanya didapatkan dari penyampaian materi pelajaran oleh guru tetapi dapat juga diperoleh melalui kegiatan ilmiah berdasarkan pada bukti-bukti empiris (Hosnan, 2014). Hal ini mengisyarakatkan bahwa pada hakikatnya pembelajaran IPA tidak dapat dilepaskan dari karakteristik saintifik yang mengedepankan pada proses ilmiah yang dilakukan siswa.

Kegiatan pembelajaran yang mengedepankan proses ilmiah dapat mengajarkan siswa untuk berperan sebagai seorang ilmuwan yang berpikir secara sistematis dan logis dalam upaya memecahkan suatu masalah menggunakan berbagai teknik atau metode ilmiah yang berbeda dari metode pemecahan masalah yang umumnya digunakan pada kegiatan pembelajaran tradisional. Kegiatan pembelajaran akan memberikan kebermaknaan karena tidak hanya pada lingkup teori saja tetapi juga mengkaitkannya dengan permasalahan dalam kehidupan sehari-hari dan melatih siswa untuk memecahkannya secara ilmiah. Hal ini didukung oleh hasil penelitian Fauziah, Abdullah, \& Hakim (2013) bahwa pembelajaran berbasis masalah berdampak positif terhadap peningkatan hard dan soft skills siswa.

Studi awal penelitian yang dilakukan terhadap siswa kelas V di SD Negeri Brodot I Kabupaten Jombang menunjukkan kegiatan pembelajaran di kelas masih didominasi oleh guru sebagai pusat pembelajaran atau teacher center learning. Hal ini dilihat dari hasil observasi kelas selama beberapa kali pertemuan kegiatan pembelajaran guru hanya menggunakan metode ceramah dalam menyampaikan materi pelajaran dan memberikan soal-soal latihan atau pekerjaan rumah untuk siswa. Metode ceramah memiliki kelebihan terutama untuk meningkatkan pemahaman siswa terhadap informasi tertentu yang memerlukan kemampuan siswa dalam menyimak dan menghafalkan teori dan konsep IPA yang disampaikan oleh guru secara lisan. Guru harus mempertimbangkan implementasi metode ini pada kegiatan pembelajaran IPA karena sifat pembelajarannya yang satu arah atau sumber informasi hanya berasal dari guru sehingga tidak ada interaksi antara guru dan siswa dalam kegiatan pembelajaran di kelas.

Hasil wawancara juga mengungkapkan fakta bahwa siswa mengalami kebosanan dan kurang termotivasi untuk belajar IPA ketika siswa hanya mendengarkan penjelasan guru di kelas dan mengerjakan tugas atau soal latihan. Penyampaian teori dan konsep IPA akan diterima dengan baik oleh siswa jika terjadi saling komunikasi dan interaksi dua arah antara guru dan siswa. Siswa tidak dapat hanya mendengarkan materi pelajaran yang disampaikan oleh guru tetapi siswa harus dapat membangun pengetahuannya sendiri, melatih kemampuan berpikirnya dan dapat mengembangkan keterampilan proses IPA. Kompetensi-kompetensi tersebut dapat dikuasai siswa dengan melatihkan kemampuan saintifik pada kegiatan intelektual yang konkret, rasional dan ilmiah sehingga pembelajaran IPA akan memberikan kebermaknaan bagi siswa.

Kenyataan di lapangan menunjukkan guru tidak melatihkan kemampuan saintifik kepada siswa sebagai dasar kegiatan pembelajaran IPA. Hal ini didasarkan dari hasil wawancara guru yang menjelaskan bahwa kegiatan pembelajaran IPA selama ini belum menyentuh pada kompetensi untuk melatihkan kemampuan saintifik siswa. Hasil jawaban angket siswa juga menunjukkan sebagian besar siswa tidak dapat menjawab dengan tepat beberapa pernyataan yang disajikan pada angket yang terkait dengan definisi maupun contoh indikator-indikator kemampuan saintifik yang meliputi mengamati, menanya, menalar, mencoba dan membentuk jejaring atau mengkomunikasikan (Kemendikbud, 2013). Kondisi ini merupakan hasil dari kegiatan pembelajaran yang hanya menonjolkan pada aspek akademik yang mengutamakan kuantitas teori dan konsep IPA yang dikuasai siswa dimana guru masih memegang peranan utama dalam kegiatan pembelajaran. Peran guru yang hanya sebatas pemberi informasi dan penyampai materi pelajaran dinilai kurang selaras dengan tujuan pembelajaran IPA 
yang menghendaki siswa untuk tidak hanya memiliki kemampuan dalam memahami teori dan konsep IPA tetapi juga diharapkan mampu berpikir secara kritis, kreatif dan inovatif, memiliki rasa ingin tahu yang tinggi, peduli terhadap lingkungan sekitarnya, serta mengembangkan kemampuan menggunakan konsep-konsep IPA yang dipelajarinya untuk menyelesaikan berbagai permasalahan melalui percobaan ilmiah.

Kenyataan atau fakta yang terjadi di SD Negeri Brodot I memunculkan beragam permasalahan dalam kegiatan pembelajaran IPA. Metode pembelajaran yang selama ini digunakan guru berimplikasi terhadap tidak dikuasainya keterampilan proses IPA oleh siswa sebagai salah satu pendekatan pembelajaran IPA yang didasarkan pada langkah-langkah kegiatan ilmiah untuk menguji, membangun dan membuktikan suatu teori atau konsep IPA. Siswa kelas V memiliki dasar pengetahuan yang kurang tentang keterampilan merumuskan hipotesis, menginferensi, memprediksi dan mengkomunikasikan. Guru hendaknya menyadari bahwa kegiatan pembelajaran IPA tidak terpisahkan dari keterampilan proses IPA yang digunakan sebagai metode penyelidikan pada kegiatan percobaan ilmiah. Hasil penelitian sebelumnya oleh Marjan, Aryana, \& Setiawan (2014) menunjukkan bahwa pendekatan ilmiah lebih baik daripada model pembelajaran langsung dalam meningkatkan keterampilan proses dan hasil belajar IPA. Kegiatan pembelajaran IPA ini tidak hanya sekadar memahami materi pelajaran tetapi terkait juga dengan pengetahuan dalam mengumpulkan fakta dan menghubungkannya untuk membuat suatu penafsiran dan kesimpulan.

Pemahaman siswa yang kurang terhadap keterampilan proses IPA berdampak pada rendahnya kemampuan saintifiknya. Hal ini dapat dilihat dari masalah lain yang muncul pada kegiatan pembelajaran IPA dimana siswa kelas $\mathrm{V}$ mengalami kesulitan dalam membuat pertanyaan ilmiah dari suatu deskripsi kasus, mengkaitkan keterhubungan fakta dan menemukan faktor sebab akibat antar fenomena yang menjadi dasar proses bernalar. Kemampuan saintifik tersebut perlu dikuasai siswa karena pada kegiatan percobaan ilmiah siswa akan menggunakan satu atau lebih kemampuan saintifik secara bersamaan, misalnya percobaan ilmiah tentang tumbuhan hijau (berklorofil) yang memerlukan kemampuan mengamati, menanya dan mencoba, atau percobaan ilmiah tentang pernapasan manusia yang memerlukan kemampuan mengamati, menanya, menalar dan membuat jejaring dengan pengetahuan lainnya. Aktivitas saintifik pada kegiatan percobaan ilmiah menjadikan kegiatan pembelajaran IPA tidak hanya menitikberatkan pada kemampuan kognitif siswa tetapi juga membuat siswa lebih aktif mengkonstruksi pengetahuan berdasarkan informasi dan fakta yang ditemukannya (Sani, 2014:15). Pengkonstruksian informasi dan fakta ini dimaksudkan untuk memberikan pemahaman kepada siswa bahwa penguasaan teori dan konsep IPA tidak hanya didapatkan dari penyampaian materi pelajaran oleh guru di kelas tetapi juga diperoleh melalui aktivitas saintifik berdasarkan pada bukti-bukti empiris yang operasional (Hosnan, 2014:134).

Peneliti menawarkan beberapa solusi alternatif untukmengatasi masalahyangmunculdarikenyataan atau fakta yang terjadi di SD Negeri Brodot I. Solusi alternatif tersebut diantaranya adalah menggunakan model pembelajaran berbasis inkuiri terbimbing (guided inquiry), menyajikan permasalahan IPA yang dapat dijawab melalui kegiatan percobaan ilmiah, menggunakan alat dan media pembelajaran yang dapat menstimulus keterampilan proses IPA dan mengembangkan Lembar Kerja Siswa (LKS) yang dapat melatihkan kemampuan saintifik siswa. Peneliti memilih satu solusi alternatif yang didasarkan pada kajian teoritis dan empiris dapat mengatasi permasalahan di SD Negeri Brodot I, yaitu mengembangkan LKS berbasis saintifik yang akan diimplementasikan dalam kegiatan pembelajaran. LKS yang dikembangkan pada penelitian ini akan menyajikan beragam situasi masalah kontekstual yang mendukung pembelajaran bermakna bagi siswa berdasarkan investigasi, penyelidikan dan kegiatan ilmiah. Manfaat LKS sendiri dalam pembelajaran menurut Choo, Rotgans, Yew, \& Schmidt (2011) bahwa LKS dapat membimbing siswa untuk meningkatan hasil belajarnya jika sesuai dengan tahap berpikirnya. LKS dapat membantu siswa menemukan fakta melalui kegiatan percobaan ilmiah dan memotivasi mereka untuk menemukan solusi dari suatu permasalahan secara mandiri.

LKS yang dikembangkan pada penelitian ini, selain melatihkan kemampuan saintifik, juga akan melatihkan keterampilan berpikir kritis siswa kelas V di SD Negeri Brodot I. Berpikir kritis tersebut menurut Amir (2015) merupakan bagian dari pola berpikir tingkat tinggi yang terjadi dalam sistem kognitif siswa untuk membandingkan antara penge- 
tahuan yang dimilikinya dengan permasalahan yang dihadapinya. Keterampilan berpikir kritis menggunakan dasar proses berpikir untuk menganalisis argumentasi dan memunculkan gagasan terhadap setiap interpretasi sehingga siswa dapat mengembangkan pola penalaran yang logis. Keterampilan berpikir kritis menuntut upaya siswa untuk memeriksa setiap bukti dan informasi yang relevan sehingga dapat digunakan untuk mendukung pengambilan keputusan. Pada penelitian ini keterampilan berpikir kritis yang dilatihkan kepada siswa adalah keterampilan berpikir sesuai dengan indikator-indikator keterampilan berpikir kritis untuk menyelesaikan masalah yang diajukan guru berdasarkan bukti dan informasi yang valid sehingga dapat memberikan kesimpulan dan keputusan yang logis dari permasalahan yang dihadapi siswa. Pada penelitian ini dikembangkan lima indikator keterampilan berpikir kritis yang diadaptasi dari indikator keterampilan berpikir kritis yaitu mendefinisikan masalah, merumuskan hipotesis, merumuskan variabel percobaan, menganalisis dan merumuskan kesimpulan.

Peneliti merumuskan masalah pada penelitian ini berdasarkan uraian kenyataan, harapan dan masalah yang terjadi di SD Negeri Brodot I dengan sebuah pertanyaan, yaitu bagaimana kelayakan LKS saintifik untuk melatihkan keterampilan berpikir kritis siswa kelas V di SD Negeri Brodot I. Berdasarkan pertanyaan tersebut, penelitian ini memiliki tiga tujuan, yaitu menguji validitas LKS saintifik, mendeskripsikan kepraktisan LKS saintifik dan mendeskripsikan ke-efektifan LKS saintifik. Validitas LKS akan berkaitan dengan validitas konseptual dan keterbacaan LKS, kepraktisan LKS berkaitan dengan keterlaksanaan kegiatan pembelajaran dan kendala yang dihadapi dalam kegiatan pembelajaran, dan ke-efektifan LKS berkaitan dengan kemampuan saintifik, keterampilan berpikir kritis, aktivitas dan respon siswa selama pelaksanaan penelitian ini. Untuk mencapai tujuan pada penelitian ini, peneliti merencanakan suatu penelitian yang berjudul "Pengembangan Lembar Kerja Siswa (LKS) berbasis Saintifik untuk Melatihkan Keterampilan Berpikir Kritis Siswa Kelas V SD Negeri Brodot I Kabupaten Jombang".

\section{METODE}

Penelitian pengembangan Lembar Kerja Siswa (LKS) berbasis saintifik untuk melatihkan keterampilan berpikir kritis siswa kelas $\mathrm{V}$ di SDN
Brodot I di Kabupaten Jombang ini didasarkan pada metode penelitian Research And Development $(R \& D)$. Metode penelitian ini digunakan untuk menghasilkan produk tertentu dan menguji keefektifannya (Sugiyono, 2009:87). Pada bidang pendidikan, metode $R \& D$ diarahkan untuk mengembangkan dan menguji bahan ajar (Sukmadinata, 2005:54). Metode $R \& D$ dalam penelitian ini terdiri dari tiga tahapan penelitian, yang diadaptasi dari Borg \& Gall (2001), yaitu tahap studi pendahuluan, tahap pengembangan LKS dan tahap pengujian LKS berbasis saintifik untuk melatihkan keterampilan berpikir kritis. Subyek penelitian adalah siswa kelas V SD Negeri Brodot I, Kabupaten Jombang, tahun akademik 2017/2018. Subyek penelitian pada setiap uji coba memiliki perbedaan dalam hal jumlah siswa yang diikutsertakan dalam implementasi kegiatan pembelajaran. Pada uji coba pertama, penelitian dilakukan pada kelas kecil yang berjumlah enam siswa, sedangkan uji coba kedua dilakukan sebanyak dua replikasi dengan jumlah 29 siswa. Penelitian ini menggunakan empat teknik pengumpulan data yaitu validasi LKS, observasi, tes, dan angket. Validasi LKS digunakan untuk mengetahui kebenaran perangkat pembelajaran yang telah dikembangkan oleh peneliti. Observasi digunakan untuk memperoleh data penelitian tentang keterlaksanaan Rencana Pelaksanaan Pembelajaran (RPP), aktivitas siswa dan kendala-kendala selama kegiatan pembelajaran. Tes digunakan untuk memperoleh data penelitian tentang kemampuan saintifik dan ketrampilan berpikir kritis yang dilatihkan kepada siswa. Angket digunakan untuk memperoleh data tentang respon siswa terhadap kegiatan pembelajaran.

Tahap studi pendahuluan merupakan langkah awal dari pengembangan LKS. Studi pendahuluan meliputi studi pustaka, konsultasi pakar dan identifikasi awal penelitian atau kegiatan observasi kelas untuk mengamati kegiatan pembelajaran yang dilakukan guru di kelas V. Tahap ini bertujuan untuk menetapkan masalah-masalah yang dihadapi dalam kegiatan pembelajaran. Tahap ini juga memaparkan fakta-fakta yang terjadi di lapangan, harapan yang diinginkan guru terhadap kegiatan pembelajaran dan solusi alternatif yang dapat ditawarkan peneliti untuk menyelesaikan masalah. Pada tahap ini dilakukan beberapa analisis yang meliputi analisis kebutuhan, analisis siswa, analisis tugas, analisis konsep dan perumusan indikator/tujuan pembela- 
jaran. Tahap pengembangan bertujuan untuk menyusun LKS berbasis kemampuan saintifik untuk melatihkan keterampilan berpikir kritis yang akan diimplementasikan dalam kegiatan pembelajaran. Pada tahap pengembangan LKS peneliti melakukan kegiatan penelitian untuk merancang dan melakukan validasi terhadap LKS yang dikembangkan pada penelitian ini untuk dilakukan uji coba pertama pada kelas kecil dengan jumlah kurang dari sepuluh siswa. Tahap ini meliputi penyusunan instrumen evaluasi, desain awal LKS dan validasi pakar. Tahap uji coba dilakukan dengan mengujicoba LKS dalam kegiatan pembelajaran untuk melatihkan keterampilan berpikir kritis siswa kelas V SD Negeri Brodot I. Pada tahap ini, peneliti melakukan uji coba kedua di kelas V sebanyak dua replikasi untuk mendapatkan jawaban atas pertanyaan-pertanyaan pada rumusan masalah penelitian. Uji coba LKS dilaksanakan untuk menganalisis dan merevisi LKS yang telah dikembangkan sehingga dapat memberikan hasil yang optimal. LKS yang telah dikembangkan akan diujicobakan dalam kegiatan pembelajaran menggunakan desain penelitian one group pretest-posttest design.

Data pre-test dan post-test akan dianalisis tingkat kemampuan saintifik dan keterampilan berpikir kritis siswa menggunakan analisis n-gain. Analisis n-gain didasarkan pada rubrik penilaian kemampuan saintifik dan keterampilan berpikir kritis yang diadaptasi dari The Facione and Facione Holistic Scoring Rubric (Pierce, 2009). Gain menunjukkan perbedaan penguasaan kemampuan saintifik dan keterampilan berpikir kritis siswa sebelum dan setelah implementasi penelitian atau perlakuan. Gain skor ternominalisasi menunjukkan tingkat keefektifan perlakuan daripada perolehan skor atau posttest. $N$-gain dirumuskan oleh Hake (1999) sebagai berikut :

$$
\%<g>=\frac{(\%<S f-S i>)}{(100-\%<S i>)}
$$

Keterangan:

$$
\begin{array}{ll}
<\mathrm{g}> & =\text { indeks gain }(\text { n-gain }) . \\
<\mathrm{Si}> & =\text { perolehan skor saat } \text { pre-test } . \\
<\mathrm{Sf}> & =\text { perolehan skor saat post-test } .
\end{array}
$$

Kriteria $n$-gain terbagi atas tiga tingkatan, yaitu: Gain-tinggi : $<\mathrm{g}>\geq 0,7$

Gain-sedang $\quad: 0,7><\mathrm{g}>\geq 0,3$

Gain-rendah $\quad:<\mathrm{g}><0,3$

\section{HASIL}

Validitas LKS saintifik dinilai oleh dua praktisi atau ahli pada bidang pendidikan IPA dan memiliki pemahaman tentang pengembangan perangkat pembelajaran untuk siswa pada tingkat pendidikan dasar. Dua ahli bidang pendidikan IPA yang bertindak sebagai validator pada penelitian ini adalah Dr. Wirawan Fadly, M.Pd. dan Arfiati Ulfa U., S. Pd., M.Pd. Kedua validator tersebut menilai tingkat validitas LKS saintifik pada beberapa aspek atau kriteria penilaian, yaitu aspek materi, aspek penyajian, aspek kebahasaan dan aspek keterbacaan, serta hal-hal lainnya yang berpengaruh terhadap kualitas LKS saintifik. Proses validasi LKS saintifik dilakukan sebelum uji coba pertama pada kelas terbatas dengan jumlah subyek penelitian sebanyak enam siswa dan uji coba kedua di kelas V dengan dua kali replikasi. Validator tidak hanya menilai LKS saintifik yang dikembangkan pada penelitian ini tetapi juga menilai perangkat pembelajaran lainnya, seperti RPP, soal pre-test dan post-test, serta buku ajar. Hasil validasi perangkat pembelajaran dapat dikategorikan layak untuk diimplementasikan dalam kegiatan pembelajaran IPA. Hal ini didasarkan pada skor penilaian validator yang terlihat pada tabel 1 .

Validitas perangkat pembelajaran dapat dilihat dari validitas konseptual perangkat pembelajaran yang terkait dengan kesesuaian antara kompetensi dasar, kajian materi pembelajaran dan tujuan/indikator pembelajaran. Selain validitas konseptual perangkat pembelajaran, validitas perangkat pembelajaran juga ditentukan berdasarkan keterbacaan perangkat pembelajaran sehingga dapat diketahui tingkat keterbacaan perangkat pembelajaran yang dikembangkan pada penelitian ini. Keterbacaan perangkat pembelajaran merupakan salah satu faktor yang menentukan ketercapaian indikator atau tujuan pembelajaran.

Pada penelitian ini dilakukan uji rumpang (cloze procedure) untuk melihat tingkat keterbacaan LKS saintifik dan BAS. Uji rumpang dilakukan dengan mengambil beberapa paragraf dari LKM dan BAM kemudian setiap kata ke-lima dalam paragraf tersebut dikosongkan. Persentase tingkat keterbacaan LKS dan BAS dihitung dengan membandingkan banyaknya kata yang diisi benar dengan jumlah kata yang harus diisi. Sesuai dengan kriteria keterbacaan perangkat pembelajaran menurut McKamey (2006), tingkat keterbacaan LKS dan BAS dapat dibagi menjadi tiga kategori, yaitu (1) mudah dibaca dan 
Tabel 1. Hasil Validasi Perangkat Pembelajaran

\begin{tabular}{lllll}
\hline Perangkat Pembelajaran & Aspek Penilaian & Skor (Mean) & Kategori & $\begin{array}{c}\text { Reliabilitas } \\
(\%)\end{array}$ \\
\hline \multirow{2}{*}{ RPP } & Komponen RPP & 3,8 & Sangat Baik & 91 \\
& Penulisan RPP & 3,7 & Sangat Baik & 91 \\
\hline \multirow{2}{*}{ Buku Ajar Siswa BAS) } & Kelayakan isi & 3,2 & Baik & 91 \\
& Kelayakan penyajian & 4 & Sangat baik & 100 \\
& Kelayakan bahasa & 4 & Sangat baik & 100 \\
\hline \multirow{2}{*}{ LKS Saintifik } & Komponen format & 4 & Sangat baik & 100 \\
& Komponen bahasa & 3,9 & Sangat Baik & 95 \\
& Komponen isi & 3,9 & Sangat Baik & 95 \\
\hline \multirow{2}{*}{ Pre-Test dan Post-Test } & Komponen materi & 3,6 & Sangat Baik & 91 \\
& Komponen konstruksi & 3,6 & Sangat Baik & 100 \\
& Komponen bahasa & 4 & Sangat baik & 100 \\
\hline
\end{tabular}

dipahami, (2) dapat dibaca dan dipahami, dan (3) sulit dibaca dan dipahami. Hasil uji keterbacaan LKS saintifik dan BAS menunjukkan persentase keterbacaan masing-masing sebesar 95,38\% dan 92,47\%. Persentase keterbacaan LKS saintifik dan BAS tersebut mengindikasikan bahwa susunan kalimat, ejaan dan tata bahasa dari kedua perangkat pembelajaran mudah dibaca dan dipahami oleh siswa. Salah satu faktor yang melatarbelakangi tingkat keterbacaan LKS saintifik dan BAS berada pada kategori tersebut adalah revisi yang telah dilakukan oleh peneliti pada tahap validasi perangkat pembelajaran terhadap aspek bahasa dan aspek kejelasan kalimat sesuai dengan saran validator. Persentase tingkat keterbacaan LKS saintifik lebih besar daripada persentase keterbacaan BAS. Hal ini didukung dari aktivitas siswa selama kegiatan pembelajaran yang lebih dominan untuk mengerjakan LKS saintifik daripada membaca BAS.

Penelitian ini juga menguji ke-efektifan perangkat pembelajaran yang merupakan tingkat keterapan perangkat pembelajaran yang dikembangkan terhadap kemampuan saintifik dan keterampilan berpikir kritis. Keefektifan perangkat pembelajaran dapat dilihat dari aktivitas dan respon siswa terhadap kegiatan pembelajaran, serta kemampuan saintifik dan keterampilan berpikir kritis setelah implementasi kegiatan pembelajaran. Aktivitas siswa selama kegiatan pembelajaran dilakukan oleh seorang pengamat. Persentase hasil pengamatan aktivitas siswa pada kelas replikasi I dan II disajikan pada tabel 2. Kegiatan mengerjakan LKS dan melakukan percobaan merupakan aktivitas siswa yang paling dominan pada setiap kelas replikasi. Hal ini didasarkan pada tabel 2 yang memperlihatkan persentase aktivitas siswa dalam mengerjakan LKS dan melakukan percobaan diatas $70 \%$.

Kriteria keefektifan adalah tingkat keterterapan LKS saintifik yang dikembangkan pada penelitian ini setelah kegiatan pembelajaran terhadap kemampuan saintifik dan keterampilan berpikir kritis siswa kelas V di SD Negeri Brodot I, Kabupaten Jombang. Hasil tes kemampuan saintifik dan keterampilan berpikir kritis siswa pada setiap kelas replikasi dianalisis berdasarkan nilai pre-test, post-test dan pemerolehan $n$-gain. Pre-test dan post-test didasarkan pada indikator kemampuan saintifik (mengamati, menanya, menalar, mencoba dan membentuk jejaring/mengkomunikasikan) dan indikator keterampilan berpikir kritis (pendefinisian masalah, perumusan hipotesis, perumusan variabel percobaan, analisis data dan perumusan kesimpulan). Hasil nilai pre-test dan post-test dari siswa kelas V SD Negeri Brodot I pada kelas replikasi I dan II masing-masing dapat dilihat pada Tabel 3, 4, 5 dan 6.

\section{PEMBAHASAN}

Hasil, temuan dan luaran yang dicapai pada penelitian ini terkait dengan pengembangan LKS saintifik menggunakan model pengembangan dari Borg \& Gall (2001). Model pengembangan ini akan direduksi dengan menyisihkan tahap penyebaran karena keterbatasan waktu dan biaya yang dianggarkan dalam penelitian. Pengembangan LKS saintifik akan dimulai dari tahap studi pendahuluan untuk kemudian dilanjutkan pada tahap pengem- 
Tabel 2. Persentase Pengamatan Aktivitas Siswa

\begin{tabular}{|l|c|c|}
\hline \multirow{2}{*}{\multicolumn{1}{|c|}{ Aktivitas Siswa }} & \multicolumn{2}{c|}{ Rata-rata Aktivitas Siswa (\%) } \\
\cline { 2 - 3 } & Kelas Replikasi I & Kelas Replikasi II \\
\hline Mengamati demonstrasi & 67,12 & 64,73 \\
\hline Mendengarkan penjelasan guru & 64,27 & 60,84 \\
\hline Mengajukan pertanyaan kepada guru & 40,75 & 25,92 \\
\hline Menjawab pertanyaan guru & 32,86 & 27,47 \\
\hline Membentuk kelompok & 67,03 & 66,49 \\
\hline Berdiskusi sesama anggota kelompok & 65,58 & 62,46 \\
\hline Membaca BAS & 70,18 & 68,02 \\
\hline Mengerjakan LKS & 73,93 & 71,37 \\
\hline Melakukan percobaan ilmiah & 75,74 & 73,44 \\
\hline Mengidentifikasi fakta & 65,69 & 67,28 \\
\hline Mempresentasikan hasil percobaan & 68,54 & 64,27 \\
\hline Menanggapi penyajian kelompok lain & 60,09 & 61,45 \\
\hline Menjawab pertanyaan kelompok lain & 59,28 & 61,27 \\
\hline Menyimpulkan hasil diskusi & 54,27 & 53,83 \\
\hline Perilaku yang tidak relevan & 37,89 & 41,94 \\
\hline
\end{tabular}

Tabel 3. Hasil Nilai Pre-Test dan Post-Test Kemampuan Saintifik Kelas Replikasi I

\begin{tabular}{|l|l|l|l|l|}
\hline \multirow{2}{*}{ Indikator Kemampuan Saintifik } & \multicolumn{2}{|l|}{ Rata-rata Nilai } & \multirow{2}{*}{-Gain } & \multirow{2}{*}{ Kategori N-Gain } \\
\cline { 2 - 3 } & Pre-Test & Post-Test & & \\
\hline Mengamati & 38,42 & 78,93 & 0,68 & Sedang \\
Menanya & 35,27 & 76,64 & 0,67 & Sedang \\
\hline Menalar & 32,83 & 74,32 & 0,65 & Sedang \\
\hline Mencoba & 36,52 & 80,51 & 0,69 & Sedang \\
\hline Menkomunikasikan & 34,75 & 75,46 & 0,65 & Sedang \\
\hline
\end{tabular}

Tabel 4. Hasil Nilai Pre-Test dan Post-Test Kemampuan Saintifik Kelas Replikasi II

\begin{tabular}{|l|l|l|l|l|}
\hline \multirow{2}{*}{ Indikator Kemampuan Saintifik } & \multicolumn{2}{|c|}{ Rata-rata Nilai } & \multirow{2}{*}{ N-Gain } & \multirow{2}{*}{ Kategori N-Gain } \\
\cline { 2 - 3 } & Pre-Test & Post-Test & & \\
\hline Mengamati & 37,29 & 79,26 & 0,68 & Sedang \\
Menanya & 34,72 & 77,41 & 0,67 & Sedang \\
\hline Menalar & 32,46 & 72,86 & 0,64 & Sedang \\
\hline Mencoba & 36,83 & 79,52 & 0,68 & Sedang \\
\hline Menkomunikasikan & 33,69 & 74,93 & 0,65 & Sedang \\
\hline
\end{tabular}

Tabel 5. Nilai Pre-Test dan Post-Test Keterampilan Berpikir Kritis Kelas Replikasi I

\begin{tabular}{|l|l|l|l|l|}
\hline \multirow{2}{*}{$\begin{array}{l}\text { Indikator Keterampilan } \\
\text { Berpikir Kritis }\end{array}$} & \multicolumn{2}{|l|}{ Rata-rata Nilai } & \multirow{2}{*}{ Kategori N-Gain } \\
\cline { 2 - 4 } & Pre-Test & Post-Test & & \\
\hline Pendefinisian Masalah & 39,69 & 81,56 & 0,69 & Sedang \\
Perumusan Hipotesis & 36,25 & 78,75 & 0,67 & Sedang \\
\hline Perumusan Variabel Percobaan & 34,06 & 80,63 & 0,71 & Tinggi \\
\hline
\end{tabular}




\begin{tabular}{|l|l|l|l|l|}
\hline \multirow{2}{*}{$\begin{array}{l}\text { Indikator Keterampilan } \\
\text { Berpikir Kritis }\end{array}$} & \multicolumn{2}{|l|}{ Rata-rata Nilai } & N-Gain & \multirow{2}{*}{ Kategori N-Gain } \\
\cline { 2 - 3 } & Pre-Test & Post-Test & & \\
\hline Analisis Data & 40,94 & 81,25 & 0,68 & Sedang \\
\hline Perumusan Kesimpulan & 40,63 & 79,06 & 0,65 & Sedang \\
\hline
\end{tabular}

Tabel 6. Nilai Pre-Test dan Post-Test Keterampilan Berpikir Kritis Kelas Replikasi 2

\begin{tabular}{|l|l|l|l|l|}
\hline \multirow{2}{*}{$\begin{array}{l}\text { Indikator Keterampilan } \\
\text { Berpikir Kritis }\end{array}$} & \multicolumn{2}{|l|}{ Rata-rata Nilai } & \multirow{2}{*}{ K-Gain } & \multirow{2}{*}{ Kategori N-Gain } \\
\cline { 2 - 3 } & Pre-Test & Post-Test & & \\
\hline Pendefinisian Masalah & 23,58 & 76,42 & 0,71 & Tinggi \\
Perumusan Hipotesis & 20,17 & 76,70 & 0,71 & Tinggi \\
\hline Perumusan Variabel Percobaan & 23,01 & 75,00 & 0,70 & Tinggi \\
\hline Analisis Data & 21,88 & 79,26 & 0,73 & Tinggi \\
\hline Perumusan Kesimpulan & 21,59 & 76,99 & 0,71 & Tinggi \\
\hline
\end{tabular}

bangan dan tahap uji coba. Ketiga tahapan tersebut masing-masing memiliki karakteristik langkah kerja yang berbeda antara satu tahap dengan tahap lainnya, misalnya tahap pendefinisian yang terdiri dari lima langkah kerja, yaitu, diantaranya, analisis kebutuhan, analisis siswa, analisis konsep dan perumusan tujuan atau indikator pembelajaran, dan tahap pengembangan yang terdiri dari sebelas langkah kerja.

Pada penelitian ini setiap langkah kerja telah dilakukan oleh peneliti secara runut sesuai dengan pedoman pengembangan perangkat pembelajaran sehingga tercapai tujuan penelitian dan rumusan masalah yang menjadi pertanyaan penelitian. Tujuan dari penelitian ini adalah terwujudnya LKS saintifik yang valid dan layak untuk melatihkan keterampilan berpikir kritis bagi siswa kelas V di SD Negeri Brodot I, Kabupaten Jombang. LKS saintifik yang valid dan layak dapat dilihat dari beberapa kriteria, yaitu validitas LKS saintifik, kepraktisannya dan ke-efektifan perangkat pembelajaran tersebut dalam melatihkan keterampilan berpikir kritis. Berdasarkan ketiga kriteria tersebut, tujuan penelitian dapat dijabarkan menjadi tujuan-tujuan yang lebih terperinci yaitu bagaimana menguji validitas dan kepraktisan LKS saintifik secara operasional, serta bagaimana mengukur keterampilan berpikir kritis siswa setelah implementasi kegiatan pembelajaran. Untuk menjawab pertanyaan-pertanyaan penelitian tersebut, pada penelitian ini tidak hanya dikembangkan LKS saintifik tetapi juga dikembangkan perangkat pembelajaran lainnya, seperti Rencana Pelaksanaan Pembelajaran (RPP), Buku Ajar Siswa (BAS) dan lembar evaluasi siswa berupa soal-soal pre-test dan post-test yang akan mengukur kemampuan saintifik dan keterampilan berpikir kritis. Hal ini penting untuk dilakukan karena perangkat pembelajaran tersebut (RPP, BAS, pre-test/post-test dan LKS saintifik) merupakan satu kesatuan komponen pembelajaran yang saling terkait dan saling mendukung kegiatan pembelajaran di kelas.

Tabel 5 memperlihatkan perangkat pembelajaran memperoleh rata-rata skor penilaian berkisar antara 3,2-4 dengan tingkat reliabilitas diatas 90\%. Perangkat pembelajaran RPP mendapatkan rata-rata skor penilaian validasi untuk aspek komponen dan aspek penulisan masing-masing sebesar 3,7 dan 3,8. Sesuai dengan kriteria validitas perangkat pembelajaran, kedua aspek penilaian RPP tersebut berkategori sangat baik. Sementara itu, BAS mendapatkan rata-rata skor penilaian validasi sebesar 3,2 (berkategori baik) untuk aspek kelayakan isi dan 4 (berkategori sangat baik) untuk aspek kelayakan penyajian dan bahasa. Hasil validasi LKS saintifik pada setiap aspek penilaian mendapatkan kategori sangat baik, yaitu rata-rata skor 4 untuk aspek komponen format dan 3,9 untuk aspek komponen bahasa dan komponen isi. Demikian juga halnya dengan pre-test dan post-test (tes kemampuan saintifik dan ke-terampilan berpikir kritis). Hasil validasi dari setiap aspek penilaian tes kemampuan saintifik dan keterampilan berpikir kritis mendapatkan kategori sangat baik. Aspek komponen materi dan konstruksi dari tes kemampuan saintifik dan keterampilan berpikir kritis mendapatkan rata-rata skor penilaian sebesar 3,6, sedangkan aspek komponen bahasa mendapatkan rata-rata skor penilaian sebesar 4. Jika dilihat berdasarkan persentase reliabilitas untuk se- 
tiap aspek penilaian validitas perangkat pembelajaran, RPP memperoleh persentase reliabilitas sebesar $91 \%$, BAS memperoleh persentase reliabilitas berkisar antara 91\% - 100\% dan LKS saintifik memperoleh persentase reliabilitas berkisar antara $95 \%$ $100 \%$. Sementara itu, tes kemampuan saintifik dan keterampilan berpikir kritis memperoleh persentase reliabilitas berkisar antara $91 \%-100 \%$.

Perangkat pembelajaran yang telah dinilai oleh validator mengalami beberapa kali revisi dan perbaikan, baik dari segi konten atau isi penyajian, sistematika, maupun komponen bahasa. Proses revisi dari perangkat pembelajaran selama pelaksanaan penelitian ini dijelaskan sebagai berikut. Revisi RPP dilakukan terhadap aspek penentuan alokasi waktu kegiatan pembelajaran. Sehubungan dengan hal tersebut, Prastowo (2015:106) menyatakan bahwa jika kegiatan pembelajaran melibatkan aktivitas siswa untuk membaca literatur, membentuk kelompok dan berkolaborasi, melakukan percobaan dan mempresentasikan hasil percobaan maka guru hendaknya melakukan penambahan waktu belajar untuk memberikan kesempatan kepada siswa dalam memahami materi pembelajaran, melakukan percobaan dan menyelesaikan masalah yang dihadapinya. Selain aspek penentuan alokasi waktu, revisi juga dilakukan terhadap kegiatan pembelajaran yang terbagi menjadi tiga kegiatan pembelajaran, yaitu kegiatan pendahuluan, kegiatan inti dan kegiatan penutup. Dalam kegiatan inti, RPP seharusnya memuat penggalan-penggalan untuk melihatketercapaian setiap indikator/tujuan kegiatan pembelajaran. Berdasarkan penggalan-penggalan tersebut, guru dapat melakukan cek pemahaman terhadap materi pembelajaran yang belum dipahami siswa. Jika terdapat siswa yang belum menguasai konsep tertentu maka akan dilakukan remediasi pada akhir kegiatan pembelajaran (Prince, 2004:116).

Revisi LKS saintifik dilakukan terhadap aspek kejelasan kalimat dan ketepatan huruf. Aspek ketepatan huruf yang dimaksud adalah penulisan istilah. Peneliti telah melakukan revisi LKS terhadap aspek tersebut sehingga LKS dapat digunakan dalam kegiatan pembelajaran. Revisi BAS dilakukan terhadap sistematika BAS yang tidak menyertakan glosarium dan indeks. Glosarium dan indeks berguna untuk membantu siswa dalam mencari istilah dan konsep-konsep yang relevan dengan materi pembelajaran (Abrams, 1999:89). Selain revisi terhadap sistematika BAS, revisi juga dilakukan terha- dap aspek bahasa. Selama proses validasi, validator menilai bahwa dalam BAS masih terdapat kalimatkalimat yang bersifat ambigu sehingga berpotensi untuk mempunyai makna dan penafsiran ganda. Novianto \& Mustadi (2015) menyatakan bahwa dalam bahasa lisan, kalimat-kalimat yang bersifat ambigu tidak akan terjadi karena terdapat pembedaan cara pengucapan, tetapi dalam bahasa tulis, makna dan penafsiran ganda dapat terjadi jika terdapat kesalahan penulisan frasa kalimat dan antarkalimat, serta penanda ejaan yang tidak lengkap. Selain faktor-faktor yang telah dijelaskan di atas, selama penelitian masih ditemukan beberapa aspek dari BAS yang masih mengalami kesalahan. Aspekaspek tersebut diantaranya adalah aspek ketepatan penggunaan huruf, aspek penyajian konsep, aspek keterkaitan BAS dan aspek kemutakhiran isi. Peneliti telah melakukan revisi terhadap aspek-aspek tersebut sehingga dapat diimplementasikan dalam kegiatan pembelajaran.

Kegiatan pembelajaran yang diimplementasikan pada penelitian ini dilakukan pada dua kelas replikasi, yaitu kelas replikasi I dan kelas replikasi II. Kelas replikasi I terdiri dari 22 siswa, sedangkan kelas replikasi II terdiri dari 20 siswa. Berdasarkan hasil observasi yang dilakukan oleh pengamat, pada kegiatan pendahuluan untuk setiap kelas replikasi guru dapat memotivasi siswa dengan baik. Selain itu, guru dapat menyampaikan tujuan pembelajaran dengan baik, tetapi pada aspek apersepsi dan mengkomunikasikan materi prasyarat kurang dapat diorganisir dengan baik. Hal ini karena siswa mengalami konflik kognitif antara pengetahuan awal yang dimilikinya dengan pengetahuan baru yang disampaikan guru. Pada kegiatan inti, pada setiap kelas replikasi guru memberikan tanggung jawab kepada siswa untuk melakukan percobaan secara mandiri. Guru memberikan bantuan (scaffolding/ mediated learning) kepada siswa sebatas pada pendefinisian masalah, sementara kegiatan pembelajaran untuk merumuskan hipotesis sampai dengan mengkomunikasikan atau membuat jejaring dilakukan secara mandiri oleh siswa. Hal ini sesuai dengan pendapat Nur (2008:8) yang menyatakan bahwa guru dapat memberikan bantuan selama tahap awal pembelajaran dan secara bertahap mengurangi bantuan tersebut untuk memberikan kesempatan kepada siswa mengambil alih tangung jawab. Pendapat Nur (2008:8) didukung oleh Kulthau (2007:104) yang menyatakan bahwa guru dapat membimbing siswa 
dengan membangun pengetahuan dan pemahaman menuju kemandirian dan tanggungjawab pribadi.

Kegiatan pendahuluan pada kelas replikasi I terlaksana dengan baik, sedangkan kelas replikasi II terlaksana dengan cukup baik. Hal ini didasarkan pada rata-rata nilai pengamatan dan reliabilitas untuk setiap kelas replikasi yang memperoleh rata-rata nilai pengamatan sebesar 3,3 (reliabilitas 83\%) untuk kelas replikasi I dan 3,3 (reliabilitas $81 \%$ ) untuk kelas replikasi II. Pada kegiatan inti, setiap kelas replikasi memperoleh rata-rata nilai pengamatan masing-masing sebesar 3,5 dan 3,3. Hal ini menunjukkan bahwa kegiatan pembelajaran pada kegiatan inti terlaksana dengan baik untuk kelas replikasi I, sedangkan kelas replikasi II terlaksana cukup baik. Hal serupa juga terjadi pada kegiatan penutup. Pada kegiatan penutup, kelas replikasi I terlaksana dengan baik sedangkan kelas replikasi II terlaksana cukup baik. Selama kegiatan pembelajaran, beberapa siswa masih mengalami kesulitan dalam mengajukan hipotesis, menentukan prosedur percobaan dan merumuskan variabel-variabel percobaan. Siswa juga terlihat belum sepenuhnya melakukan apa yang seharusnya menjadi tanggung jawab mereka secara mandiri. Oleh karena itu, peran guru sangat terlihat dalam kegiatan inti untuk melakukan bimbingan kepada setiap kelompok dan mengingatkan siswa untuk memupuk kemandirian dalam kegiatan pembelajaran. Pada kegiatan penutup, pengamat memberikan penilaian bahwa guru mampu membimbing siswa untuk merangkum hasil kegiatan pembelajaran dan melakukan evaluasi. Guru dapat membawa siswa pada zona perkembangan terdekat (zone of proximal development) yang dimilikinya. Selain itu, guru menerapkan pemrosesan transfercocok (transfer-appropriate processing) dengan mengkaitkan antara materi pembelajaran dengan kenyataan dalam kehidupan sehari-hari siswa.

Berdasarkan data pada Tabel 3 dan 4 dapat ditunjukkan bahwa pada kelas replikasi I didapatkan rata-rata $n$-gain berkategori sedang yang ditunjukkan dengan nilai $n$-gain sebesar 0,67 dan rata-rata $n$-gain pada kelas replikasi II sebesar 0,66 . Indikator kemampuan saintifik yang dominan pada kelas replikasi I adalah indikator mencoba sebesar 0,69, sedangkan pada kelas replikasi II $n$-gain tertinggi diperoleh indikator mengamati dan mencoba dengan $n$-gain masing-masing sebesar 0,68. Sedangkan pada pada Tabel 5 dan 6 dapat ditunjukkan bahwa pada kelas replikasi I didapatkan rata-rata $n$-gain berkategori tinggi yang ditunjukkan dengan nilai $n$-gain sebesar 0,68 dengan peningkatan rata-rata $n$-gain pada kelas replikasi II sebesar 0,71. Indikator keterampilan berpikir kritis yang dominan pada kelas replikasi I adalah indikator perumusan variabel percobaan sebesar 0,71 , sedangkan pada kelas replikasi II $n$-gain tertinggi diperoleh indikator analisis data dengan $n$-gain 0,73 .

Pemerolehan nilai $n$-gain merepresentasikan hasil observasi dari kegiatan pembelajaran pada dua kelas replikasi memperlihatkan kemampuan guru dalam memotivasi siswa, melakukan apersepsi dan penyampaian materi prasyarat materi pelajaran yang akan dipelajari oleh siswa kelas V di SD Negeri Brodot I. Guru memberikan tanggung jawab kepada siswa untuk melakukan praktikum secara mandiri dengan memberikan bantuan (scaffolding/ mediated learning) kepada siswa sebatas pada pendefinisian masalah, sementara kegiatan pembelajaran untuk merumuskan hipotesis sampai dengan perumusan kesimpulan dilakukan secara mandiri. Guru dapat memberikan bantuan selama tahap awal pembelajaran dan secara bertahap mengurangi bantuan tersebut untuk memberikan kesempatan kepada siswa mengambil alih tangung jawab untuk menyelesaikan masalah (Nur, 2008:12). Brickman (2009:130) menyatakan bahwa kegiatan pembelajaran yang mengimplementasikan perangkat pembelajaran saintifik dapat melatihkan kemampuan berpikir kritis sehingga siswa dapat mengkonstruksi pengetahuannya secara mandiri. Amir \& Kusuma (2018) juga berpendapat bahwa implementasi perangkat pembelajaran saintifik dalam kegiatan pembelajaran dapat meningkatkan hasil belajar siswa dengan mengaplikasikan konsepkonsep IPA dalam kehidupan sehari-hari.

Kegiatan pembelajaran untuk mengaplikasikan konsep IPA ini memerlukan peran serta guru dalam penelitian ini untuk mempersiapkan alat dan bahan percobaan serta melakukan pembimbingan secara langsung dengan menunjukkan alat dan bahan percobaan yang akan digunakan beserta tata cara penggunaannya. Tujuan dari kegiatan peran serta guru ini adalah membimbing siswa ke arah berpikir yang sesuai dengan prosedur percobaan. Hal ini memiliki banyak manfaat yaitu perhatian siswa dapat dipusatkan pada hal-hal yang dianggap penting, dapat mendukung efisiensi waktu kegiatan pembelajaran, dapat mengurangi kesalahan yang 
dilakukan siswa selama kegiatan praktikum, guru dapat memberikan scaffolding kepada siswa selama kegiatan percobaan dan permasalahan yang menimbulkan pertanyaan atau keraguan pada benak siswa dapat diatasi selama kegiatan pembelajaran.

\section{SIMPULAN DAN SARAN}

\section{Simpulan}

Berdasarkan temuan-temuan penelitian yang telah dipaparkan dapat disimpulkan bahwa Lembar Kerja Siswa (LKS) yang dikembangkan pada penelitian ini memenuhi kriteria validitas, kepraktisan dan keefektifan sehingga layak untuk diimplementasikan dalam kegiatan pembelajaran IPA di kelas V untuk melatihkan kemampuan saintifik dan keterampilan berpikir kritis. Validitas LKS akan berkaitan dengan validitas konseptual dan keterbacaan LKS, kepraktisan LKS berkaitan dengan keterlaksanaan kegiatan pembelajaran dan kendala yang dihadapi dalam kegiatan pembelajaran, dan keefektifan LKS berkaitan dengan kemampuan saintifik, keterampilan berpikir kritis, aktivitas dan respon siswa selama pelaksanaan penelitian ini.

\section{Saran}

Berdasarkan penelitian yang telah dilakukan, peneliti menyarankan untuk (1) perlu adanya kegiatan pra-laboratorium sebelum melaksanakan kegiatan pembelajaran ini sehingga dapat memberikan pengetahuan awal kepada siswa terkait dengan alat dan bahan yang akan digunakan dalam kegiatan percobaan ilmiah, (2) LKS berbasis kemampuan saintifik perlu dikembangkan secara lebih luas pada materi pelajaran IPA lainnya, (3) implementasi kegiatan pembelajaran berdasarkan kemampuan saintifik memerlukan pengelolaan waktu yang cermat sehingga harus dirancang secara lebih sistematis dan efisien dengan tetap memberikan kesempatan kepada siswa untuk melatihkan kemampuan saintifik dan keterampilan berpikir kritis.

\section{DAFTAR RUJUKAN}

Abrams, S. 1999. Physics A Window An Our World Student Learning Guide. Prentice-Hall: Englewood.

Amir, M.F. 2015. Proses Berpikir Kritis Siswa Sekolah Dasar Dalam Memecahkan Masalah
Berbentuk Soal Cerita Matematika Berdasarkan Gaya Belajar. Jurnal Math Education Nusantara, 1 (2). Dari http://ojs.unpkediri. ac.id/index.php/matematika/article/view/235.

Amir, M.F., \& Kusuma, M.D. 2018. Pengembangan Perangkat Pembelajaran Berbasis Masalah Kontekstual untuk Meningkatkan Kemampuan Metakognisi Siswa Sekolah Dasar. Journal of Medives, 2 (1).

Borg, W., \& Gall, M. 2001. Education Research. New York: Allyn and Bacon.

Brickman, P. 2009. Effects of Inquiry-Based Learning on Students' Science Literacy Skills and Confidence. International Journal for The Scholarship of Teaching and Learning, 3 (2).

Choo, S.S.Y., Rotgans, J.I., Yew, E.H.J., \& Schmidt, H.G. 2011. Effect Of Worksheet Scaffolds On Student Learning In Problem-Based Learning. Journal Spring Nature, 2(1).

Fauziah, R., Abdullah, A.G., \& Hakim, D.L. 2013. Pembelajaran Saintifik Elektronika Dasar Berorientasi Pembelajaran Berbasis Masalah. Journal Invotec, 9 (2).

Hosnan, M. 2014. Pendekatan Saintifik dan Kontekstual dalam Pembelajaran Abad 21. Bogor: Ghalia Indonesia.

Kemendikbud, 2013. Pendekatan Scientific (Ilmiah) dalam Pembelajaran. Jakarta: Pusbangprodik.

Kemendikbud, 2013. Pengembangan Kurikulum 2013. Paparan Mendikbud dalam Sosialisasi Kurikulum. Jakarta: Kemendikbud.

Kulthau, C. 2007. Guided Inquiry: A Framework for Independent Learning. USA: Rutgers University.

Marjan, J., Aryana, P.B., \& Setiawan, I.G.A. 2014. Pengaruh Pembelajaran Pendekatan Saintifik Terhadap Hasil Belajar Biologi Dan Keterampilan Proses Sains Siswa MA. MU Allimat NW Pancor Selong Kabupaten Lombok Timur Nusa Tenggara Barat. Jurnal Ilmu Pengetahuan Alam, 4 (1).

Novianto, A., \& Mustadi, A. 2015. Analisis Buku Teks Muatan Tematik Integratif, Scientific Approach, dan Authentic Assessment Sekolah Dasar. Jurnal Kependidikan, 45 (1).

Nur, M. 2008. Pengembangan Model PBM IPA Berorientasi PKP untuk Meningkatkan Daya Nalar Siswa dalam Rangka Menyongsong Masyarakat IPTEK pada Pembangunan Jangka 
90 Sekolah Dasar: Kajian Teori dan Praktik Pendidikan, Tahun 26 Nomor 1, Mei 2017, hlm 79-90

Panjang Kedua. Makalah yang Disajikan pada Seminar Nasional IKIP Surabaya, Jurusan Pendidikan IPA, 3 April.

Nur, M. 2008. Buku Panduan Keterampilan Proses dan Hakikat Sains. Surabaya: Univesrity Press.

Nur, M. 2008. Pengajaran Berpusat Kepada Siswa dan Pendekatan Kontruktivistik dalam Pengajaran. Surabaya: PSMS Unesa.

Prastowo, A. 2015. Menyusun Rencana Pelaksanaan Pembelajaran (RPP) Tematik Terpadu Implementasi Kurikulum 2013. Jakarta: KENCANA.
Prince, D. 2004. How Students Learn: Science in the Classroom. Washington DC: The National Academies Press.

Sani, R. A. 2014. Pembelajaran Saintifik untuk Implementasi Kurikulum 2013. Jakarta: PT Bumi Aksara.

Sugiyono. 2008. Metode Penelitian Kuantitatif, Kualitatif dan $R \& D$. Bandung: Alfabet.

Sukmadinata. 2007. Metode Penelitian Pendidikan. Bandung: Remaja Rosda Karya. 